Article

\title{
Enterotoxin Genes, Antibiotic Susceptibility, and Biofilm Formation of Low-Temperature-Tolerant Bacillus cereus Isolated from Green Leaf Lettuce in the Cold Chain
}

\author{
Kyung Min Park ${ }^{1,2}$, Hyun Jung Kim ${ }^{1,2}$, Mooncheol Jeong ${ }^{2}$ and Minseon Koo ${ }^{1,3, *}$ \\ 1 Food Biotechnology, Korea University of Science \& Technology, Daejeon 34113, Korea; \\ kyungmuni82@naver.com (K.M.P.); hjkim@kfri.re.kr (H.J.K.) \\ 2 Consumer Safety, Korea Food Research Institute, Wanju-gun 55365, Korea; mcjeong@kfri.re.kr \\ 3 Food Analysis Center, Korea Food Research Institute, Wanju-gun 55365, Korea \\ * Correspondence: minsk@kfri.re.kr; Tel.: +82-63-219-9161; Fax: +82-63-219-9876
}

Received: 29 January 2020; Accepted: 25 February 2020; Published: 25 February 2020

\begin{abstract}
The prevalence and characteristics of low-temperature-tolerant Bacillus cereus (psychrotolerant B. cereus) in green leaf lettuce collected during cold chain were investigated. Among the 101 isolated B. cereus samples, only 18 were capable of growth at $7^{\circ} \mathrm{C}$, and these isolates shared potential health hazard characteristics with mesophilic isolates. Most psychrotolerant $B$. cereus isolates contained various combinations of nheA, nheB, nheC, $h b l A, h b l A, h b l C, h b l D, c y t K$, and entFM. Most isolates of psychrotolerant $B$. cereus possessed at least two enterotoxin genes and $28 \%$ of isolates harbored tested nine enterotoxin genes. Additionally, the psychrotolerant B. cereus isolates showed resistance to tetracycline and rifampin and intermediate levels of resistance to clindamycin. A total of $23 \%$ of isolates among psychrotolerant $B$. cereus displayed a high level of biofilm formation at $7{ }^{\circ} \mathrm{C}$ than at $10^{\circ} \mathrm{C}$ or $30^{\circ} \mathrm{C}$. The results of this study indicate that cold distribution and storage for green leaf lettuce may fail to maintain food safety due to the presence of enterotoxigenic, antibiotic-resistant, and strong biofilm forming psychrotolerant $B$. cereus isolates, which therefore poses a potential health risk to the consumer. Our findings provide the first account of the prevalence and characteristics of psychrotolerant $B$. cereus isolated from green leaf lettuce during cold storage, suggesting a potential hazard of psychrotolerant $B$. cereus isolates to public health and the food industry.
\end{abstract}

Keywords: low-temperature tolerant; Bacillus cereus; enterotoxin gene; antibiotic susceptibility; biofilm formation; cold chain

\section{Introduction}

Temperature is one of the crucial factors affecting the safety and quality of vegetables and fruits [1]. To inhibit the growth of foodborne pathogens, vegetables must be maintained at refrigeration temperatures throughout all steps from harvest to consumption. The temperature of perishable foods such as fruits and vegetables must be controlled throughout the supply chain using cold chain systems. However, some bacteria can grow at refrigeration temperatures, and these bacteria (called phychrotolerant bacteria) have been recognized as spoilage bacteria or foodborne pathogens that cause food safety and food quality problems during refrigerated storage and the distribution process of various food products [2,3].

Bacillus cereus is an endospore-forming foodborne pathogen causing diarrheal or emetic food poisoning [4]. B. cereus is ubiquitous in soil, rive, spices, milk, and vegetables and on human skin [4]. In a previous study on the microbiological quality of fresh vegetables, the most frequent foodborne 
pathogen found in fresh vegetables was B. cereus, with a contamination rate of $37.5 \%$ [5]. The emetic type of food poisoning is caused by strains producing a heat-stable toxin called cereulide, which is encoded by the ces gene [6] and is produced in food [7]. The diarrheal type of food poisoning is caused by strains producing one or several enterotoxins produced during the growth of vegetative cells in the small intestine [8]. The enterotoxins produced by B. cereus have been described: hemolysin BL (HBL), consisting of three genes of $h b l A, h b l C$, and $h b l D$; nonhemolytic enterotoxin (NHE), encoded by nheA, nheB, and nheC; cytotoxin $\mathrm{K}$ (CytK); and enterotoxin FM (EntFM). Although B. cereus is a well-known cause of food poisoning, it is also a prolific producer of lipases and proteases and is recognized as causing spoilage in dairy products and refrigerated products [9]. Furthermore, B. cereus can attach to food contact surfaces such as pipelines and stainless steel equipment where it might germinate under optimal growth conditions [10].

The B. cereus group was not traditionally considered as a psychrotolerant species until some cold-tolerant isolates were identified in 1990. The term psychrotrotolerant is actually used for mesophlic bacteria that are low temperature tolerant and grow in a psychrophilic temperature range. Optimum growth temperature for psychrophilic bacteria is $15^{\circ} \mathrm{C}$, while psychrotolerant bacteria have a wider range as they can grow at $25-40{ }^{\circ} \mathrm{C}$, similar to their mesophilic counterparts, and can grow at temperatures at $7^{\circ} \mathrm{C}$ and below [11-13]. At low temperatures, psychrotolerant $B$. cereus has slower metabolic rates but higher catalytic efficiencies than mesophilic strains [11]. Psychrotolerant B. cereus is a contaminant in many raw materials used for food production and cold-stored foods [12,13] and can reach levels that are potentially harmful for human health during refrigerated storage [14]. Some psychrotolerant $B$. cereus strains isolated from whole liquid egg product were able to produce toxins in the food at 6,8 , and $10^{\circ} \mathrm{C}$ [15] and were found to contain the ces gene responsible for cereulide production. Psychrotolerant B. cereus are still virulent as they express toxin genes and induce cytotoxic activity to the same extent as B. cereus mesophilic strains at low temperatures [16]. Therefore, psychrotolerant $B$. cereus should be identified as a potential hazard for refrigerated foods that are subjected to temperature abuse that occurs during food shipping, distribution, and storage. These bacteria also show high resistance to other environmental stresses. In a recent study on psychrotolerant B. cereus, after refrigerated storage at $8{ }^{\circ} \mathrm{C}$ and a $\mathrm{pH}$ of 3-4, food products contained a high number of vegetative psychrotolerant $B$. cereus cells; the B. cereus strains were able to grow to an approximately $8 \log$ colony forming unit (CFU)/g after seven days [17]. Another strain of psychrotolerant B. cereus was able to grow at $10{ }^{\circ} \mathrm{C}$ under anaerobic conditions and reached 4 to $6 \log \mathrm{CFU} / \mathrm{g}$ [18]. Due to their potential to grow at low temperature, their ability to produce toxins, cross protection phenomenon to other environmental stresses, and their implications in foodborne outbreaks, psychrotolerant isolates of $B$. cereus have been of concern in the food industry.

B. cereus is sometimes connected to hospital infection such as bacteremia, central nervous system infection, respiratory infections, endocarditis, and food poisoning. The occurrence of hospital infection by $B$. cereus is low, but the mortality is high, regardless of aggressive treatment with antibiotics. Thus, the spread of antimicrobial resistant bacteria is a severe public health problem and is associated with increasing mortality and medical costs $[19,20]$. Most B. cereus isolates are susceptible to commonly used antibiotic agents except on beta-lactam antibiotics [21], however, prolonged and extensive antibiotic use has led to the emergence of single or multidrug resistant bacteria. Some B. cereus isolated from foodstuff have been reported to be resistant to tetracycline, erythromycin, and rifampin [22]. However, little is known regarding the antimicrobial resistance of psychrotolerant $B$. cereus isolated from raw vegetables. Therefore, the antimicrobial resistance of $B$. cereus isolated from foodstuff must be monitored for human health and food safety.

The presence of $B$. cereus strains in green leafy vegetables were frequently observed $[4,21,23]$. Considering green leafy vegetables are generally distributed throughout the cold chain, there is the possibility of the existence of psychrotolerant $B$. cereus strains in these types of food. Furthermore, since vegetables are consumed without further cooking, contamination of psychrotolerant $B$. cereus can remain viable, but little study was available. Only a few studies have provided information about the 
prevalence and characteristics of psychrotolerant B. cereus strains from foodstuff such as milk, dairy products, and chilled food $[17,18,24]$. Therefore, the goal of the present study was to evaluate the presence and toxigenic characteristics of $B$. cereus strains, especially psychrotolerant $B$. cereus strains in green leaf lettuce as an example of leafy vegetables distributed in cold chain. We investigated the presence of genes encoding enterotoxins, antibiotic susceptibility, and biofilm formation ability at refrigeration temperatures. The results from this study will provide an enhanced understanding of the behavior of psychrotolerant $B$. cereus strains in agricultural products distributed through the cold chain.

\section{Materials and Methods}

\subsection{Collection of Samples}

We collected the green leaf lettuce from every step of the "farm-to-retail" distributions of leafy vegetables. More detailed sampling steps were as follows: Green leaf lettuce was harvested in an open field on a farm located in Gyeongii Province, South Korea. Harvested vegetables were transported to a packing house located within the same farm where they were hand-packed into boxes at a low temperature. Samples for microbiological quality analysis were collected after harvesting (referred to as 'harvest') and packaging ('packaging'). On the same day, the packaged boxes were loaded onto refrigerated trucks for transportation and storage in a distribution center. The next samples were collected after arrival at the distribution center ('transportation') and indicated storage duration at $9-10{ }^{\circ} \mathrm{C}$ in the distribution center, prior to shipment to the retail outlet ('distribution center'). The final sampling site ('retail shop') was the point of sale in the retail shop.

The vegetable samples $(100 \mathrm{~g})$ from each sampling site were individually placed in sterilized bags from ten different boxes of the same lot code and were maintained at $5{ }^{\circ} \mathrm{C}$ during transport to the laboratory for microbiological quality analysis. The temperature of the green leaf lettuce was monitored with a continuous temperature recorder connected to a reader (BTM-4208SD, LT Lutron, Taipei, Taiwan) with a thermocouple. The thermocouple was completely inserted into the center of the vegetables. The ambient temperature ranged from $0{ }^{\circ} \mathrm{C}$ to $5^{\circ} \mathrm{C}$ and the temperature of the vegetables was maintained at $5{ }^{\circ} \mathrm{C} \pm 2{ }^{\circ} \mathrm{C}$ throughout the entire distribution chain (Figure 1).

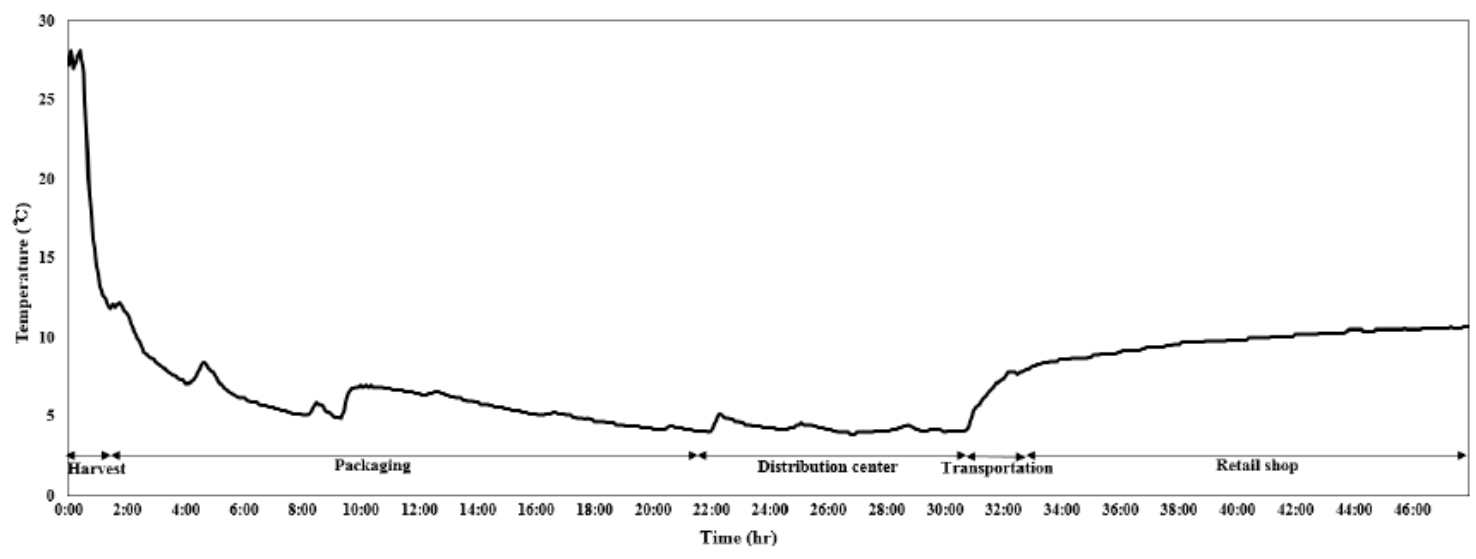

Figure 1. Product temperature recorded by temperature sensors during the cold chain.

\subsection{Microbiological Analysis for the B. cereus Group}

The microbiological procedures for B. cereus group isolation recommended by the Korean food code [25] were followed. To isolate the $B$. cereus group from green leaf lettuce collected during the supply chain, $25 \mathrm{~g}$ of each sample was transferred to a sterile stomacher bag with $225 \mathrm{~mL}$ of $0.85 \%$ saline and homogenized for $2 \mathrm{~min}$ at $230 \mathrm{rpm}$ in a stomacher 400 (Seward, Norfolk, UK). Next, the suspension solution was inoculated onto mannitol-egg-yolk-polymyxin B agar (MYP, Merck, Darmstadt, Germany) and incubated at $30^{\circ} \mathrm{C}$ for $18 \mathrm{~h}$. The B. cereus group appears as dry, pinkish colonies surrounded by a ring of dense precipitate due to the degradation of lecithin. Suspected colonies were selected, 
and a maximum of five typical colonies from each sample were subcultured on tryptic soy agar (TSA, Merck Darmstadt, Germany). Where there were less than five colonies, all were isolated. Biochemical identification of the selected colonies was conducted by using the Vitek-II system with the BCL card (bioM'erieux, Inc., Marcy l'Etoile, France), according to the manufacturer's directions.

\subsection{Bacterial DNA Extraction}

To obtain the genomic DNA, $1 \mathrm{~mL}$ of the $18-20 \mathrm{~h}$ bacterial culture was centrifuged $(15,000 \times g$, $5 \mathrm{~min}$ ) and the pellet was washed twice with $1 \mathrm{~mL}$ phosphate-buffered saline (PBS). The cell pellet was resuspended in $100 \mu \mathrm{L}$ sterilized distilled water and heated at $95^{\circ} \mathrm{C}$ for $10 \mathrm{~min}$ and was then placed on ice. After centrifugation at $14,000 \times g$ for $2 \mathrm{~min}$, the supernatant was used as the template for molecular identification and the toxin gene profile.

\subsection{Identification of B. cereus and B. thuringiensis from the B. cereus Group}

To isolate B. cereus and B. thuringiensis, Polymerase chain reaction (PCR) amplification of the gyrase B $(g y r B)$ gene and crystal ( $c r y)$ gene was carried out as described by Yamada et al. [26]. The primers used for the identification of $B$. cereus were BC1 (5'-ATTGGTGACACCGATCAAACA- $3^{\prime}$ ) and BC2r ( $5^{\prime}$-TCATACGTATGGATGTTATTC-3'). BTJH-1F (GCTTACCAGGGAAATTGGCAG) and BTJH-R (ATCAACGTCGGCGTCGG) were used for the identification of B. thuringiensis from the $B$. cereus group. The specific primers for the cry gene detection of B. thuringiensis were $\mathrm{K} 3$ (5'-GGCTGTGACACGAAGGATATAGCCAC-3') and K5 (5'-AGGACCAGGATTTACAGGAGG-3'). The amplification of gyrB (365 bp) for B. cereus-specific fragments and gyrB (299 bp) and cry for B. thuringiensis (1600 to $1700 \mathrm{bp}$ ) was performed using 30 cycles, each consisting of $60 \mathrm{~s}$ at $94^{\circ} \mathrm{C}, 90 \mathrm{~s}$ at $58^{\circ} \mathrm{C}$ (gyrB for B. cereus and cry gene for B. thurigiensis), $90 \mathrm{~s}$ at $63^{\circ} \mathrm{C}$ (gyrB for B. thurigiensis), and $90 \mathrm{~s}$ at $72{ }^{\circ} \mathrm{C}$, with a final extension step at $72{ }^{\circ} \mathrm{C}$ for $7 \mathrm{~min}$. Bacillus mycoides were identified based on the distinct characteristics of filamentous and rhizoid colonies that formed on the agar plate [27].

\subsection{Growth Properties}

To determine the psychrotolerant properties, all isolates of the B. cereus group were screened for their growth ability at $10^{\circ} \mathrm{C}, 7^{\circ} \mathrm{C}$, and $5^{\circ} \mathrm{C}$. The B. cereus group isolates were first inoculated on tryptic soy agar and incubated at $30^{\circ} \mathrm{C}$ for $18 \mathrm{~h}$. One colony of overnight culture was inoculated on a fresh TSA plate and incubated at $10^{\circ} \mathrm{C}$ for 12 days, at $7{ }^{\circ} \mathrm{C}$ for 20 days, and at $5{ }^{\circ} \mathrm{C}$ for 20 days. After incubation, the plates were examined for observable growth.

\subsection{Detection of Enterotoxin and Emetic Toxin Genes}

To assess the putative pathogenic potential of the B. cereus group isolates, all isolates were screened by PCR for the presence/absence of toxin genes known to encode enterotoxins and emetic toxins. The primer pairs for each toxin gene used in this study were based on our previous study [18]. The primer pair sequences and the conditions of amplification are listed in Table 1. B. cereus ATCC 14579 (diarrheagenic) and NCCP 14796 (emetic) strains were used as the control strains.

\subsection{Antibiotic Susceptibility Testing}

All isolates were tested using the standard disk diffusion method on Mueller-Hinton agar (Merck), as described by the Clinical and Laboratory Standards Institute [23]. The antimicrobial agents were tested and their concentrations were as follows: cefotaxime $(30 \mu \mathrm{g})$, ceftriaxone $(30 \mu \mathrm{g})$, chloramphenicol $(30 \mu \mathrm{g})$, ciprofloxacin $(5 \mu \mathrm{g})$, clindamycin $(2 \mu \mathrm{g})$, erythromycin $(15 \mu \mathrm{g})$, gentamicin $(10 \mu \mathrm{g})$, imipenem $(10 \mu \mathrm{g})$, penicillin $(10 \mu \mathrm{g})$, rifampin $(5 \mu \mathrm{g})$, tetracycline $(30 \mu \mathrm{g})$, and vancomycin $(10 \mu \mathrm{g})$. After incubation at $30^{\circ} \mathrm{C}$ for $24 \mathrm{~h}$, the antibiotic susceptibility was measured, and the results were interpreted as "susceptible", "intermediate", and "resistant" in accordance with the criteria 
provided by the Clinical and Laboratory Standards Institute [28]. Quality control was performed using the reference strain Staphylococcus aureus ATCC 29213.

Table 1. Sequences of the primers used in this study.

\begin{tabular}{|c|c|c|c|c|}
\hline $\begin{array}{c}\text { Targent } \\
\text { Gene }\end{array}$ & Primer & Sequence $\left(5^{\prime}-3^{\prime}\right)$ & Melting Temp $\left({ }^{\circ} \mathrm{C}\right)$ & Amplicon (bp) \\
\hline \multirow{2}{*}{$h b l A$} & hblA-F & GTG CAG ATG TTG ATG CCG AT & \multirow{2}{*}{55} & \multirow{2}{*}{319} \\
\hline & hblA-R & ATG CCA CTG CGT GGA CAT AT & & \\
\hline \multirow{2}{*}{$h b l C$} & hblC-F & AAT GGT CAT CGG AAC TCT AT & \multirow{2}{*}{55} & \multirow{2}{*}{749} \\
\hline & hblC-R & CTC GCT GTT CTG CTG TTA AT & & \\
\hline \multirow{2}{*}{$h b l D$} & hblD-F & AAT CAA GAG CTG TCA CGA AT & \multirow{2}{*}{55} & \multirow{2}{*}{429} \\
\hline & hblD-R & CAC CAA TTG ACC ATG CTA AT & & \\
\hline \multirow{2}{*}{ nheA } & nheA-F & TAC GCT AAG GAG GGG CA & \multirow{2}{*}{55} & \multirow{2}{*}{499} \\
\hline & nheA-R & GTT TTT ATT GCT TCA TCG GCT & & \\
\hline \multirow{2}{*}{ nheB } & nheB-F & CTA TCA GCA CTT ATG GCA G & \multirow{2}{*}{55} & \multirow{2}{*}{769} \\
\hline & nheB-R & ACT CCT AGC CGG TGT TCC & & \\
\hline \multirow{2}{*}{ nheC } & nheC-F & CGG TAG TGA TTG CTG GG & \multirow{2}{*}{55} & \multirow{2}{*}{581} \\
\hline & nheC-R & CAG CAT TCG TAC TTG CCA A & & \\
\hline \multirow{2}{*}{ entFM } & entFM-F & ATG AAA AAA GTA ATT TGC AGG & \multirow{2}{*}{55} & \multirow{2}{*}{1269} \\
\hline & entFM-R & TTA GTA TGC TTT TGT GTA ACC & & \\
\hline \multirow{2}{*}{ cytK } & cytK-F & GTA ACT TTC ATT GAT GAT CC & \multirow{2}{*}{44} & \multirow{2}{*}{505} \\
\hline & cytK-R & GAA TAC TAA ATA ATT GGT TTC C & & \\
\hline \multirow[t]{2}{*}{ ces } & ces-F & GGT GAC ACA TTA TCA TAT AAG GTG & \multirow[t]{2}{*}{55} & \multirow{2}{*}{1271} \\
\hline & ces-R & GTA AGC GAA CCT GTC TGT AAC AAC A & & \\
\hline
\end{tabular}

\subsection{Quantification of Biofilm Formation}

The biofilm formation ability of the B. cereus group isolates was performed according to the modified method by Singh et al. [29] and was investigated under different temperature conditions $\left(30^{\circ} \mathrm{C}, 10^{\circ} \mathrm{C}\right.$, and $\left.7^{\circ} \mathrm{C}\right)$ using the microtiter plate method. These temperatures were chosen due to their importance in the distribution chain of agricultural products: $30^{\circ} \mathrm{C}$ is the optimum temperature for growth of the $\mathrm{B}$. cereus group, $10^{\circ} \mathrm{C}$ is the average surface temperature of the vegetables in the distribution chain, and $7{ }^{\circ} \mathrm{C}$ is the growth temperature of the psychrotolerant $B$. cereus group isolates. To evaluate biofilm formation, all $B$. cereus group isolates were inoculated into a test tube containing $10 \mathrm{~mL}$ of tryptic soy broth (TSB, Merck) and were incubated for $18 \mathrm{~h}$ at $30^{\circ} \mathrm{C}$. A total of $100 \mu \mathrm{L}$ of each bacterial suspension was inoculated into $900 \mu \mathrm{L}$ of fresh tryptic soy broth in three wells of three sterile 48-well flat-bottomed polystyrene plates. Negative control wells containing only TSB were inoculated in triplicate.

For biofilm evaluation, we used biological triplicates. The plates were covered and incubated aerobically for $72 \mathrm{~h}$ at $30^{\circ} \mathrm{C}$, for 12 days at $10^{\circ} \mathrm{C}$, and for 20 days at $7^{\circ} \mathrm{C}$. After incubation, the contents of the microtiter plate were poured off, and the wells were washed three times with $1 \mathrm{~mL}$ of phosphate buffered saline. The attached bacteria were then fixed with $1 \mathrm{~mL}$ of methanol per well for $15 \mathrm{~min}$, after which the plates were emptied and dried at room temperature. Then, the plates were stained with $500 \mu \mathrm{L}$ of $1 \%$ crystal violet per well for $10 \mathrm{~min}$. The stain was removed, and the plates were washed under running tap water. The plates were air dried. In this study, sterile broth and B. cereus 14579 served as the negative control and B. cereus ATCC 10876 was used as the positive control strain for all incubation temperatures.

The optical density (OD) of each well was measured at $550 \mathrm{~nm}$ with a microplate reader (Synergy ${ }^{\mathrm{TM}}$ Mx, BioTek, Winooski, VT, USA). The OD of each strain was obtained from the mean value of the three respective wells. The strains were classified as follows. The cut-off OD (ODc) for the microtiter plate test was defined as three standard deviations above the mean OD of the negative control. The strains were classified into four categories: no biofilm producer (ODs $\leq \mathrm{ODc}$ ), weak biofilm producer (ODc $<$ ODs $\leq 2 \times$ ODc), moderate biofilm producer $(2 \times$ ODc $<$ ODs $\leq 4 \times$ ODc), or strong biofilm producer $(4 \times$ ODc $<$ ODs $)$. 


\subsection{Statistical Analysis}

All assays were performed in triplicate in two independent experiments, and the results were expressed as the average and log-transformed values. SPSS statistical software (IBM, Armonk, NY, USA) was used to evaluate the results by one-way analysis of variance (ANOVA). To compare the means, Duncan's test was used with a significance level of $p<0.05$.

\section{Results and Discussion}

\subsection{Prevalence and Identification of the B. cereus Group}

The prevalence and identification of the B. cereus group from green leaf lettuce throughout the cold chain are illustrated in Table 2 . The B. cereus group contaminated all samples collected at each sampling point, and the average contamination level was less than $3 \log C F U / g$. After harvest, the mean B. cereus number was $1.9 \log \mathrm{CFU} / \mathrm{g}$, and the level $(2.9 \log \mathrm{CFU} / \mathrm{g})$ of contamination at the packaging point was $1 \log \mathrm{CFU} / \mathrm{g}$ higher than that at the harvest point. During cold storage in the distribution center, the contamination level of $B$. cereus was maintained, but the average count at the transportation point decreased to $2.1 \log \mathrm{CFU} / \mathrm{g}$ from $2.6 \log \mathrm{CFU} / \mathrm{g}$ at the distribution center. Few studies have evaluated B. cereus contamination in vegetables, and approximately $50 \%$ of the tested vegetable products were contaminated with B. cereus [21,30-32]. B. cereus contamination of vegetables may be common, and the consumption of vegetables contaminated with B. cereus may result in exposure to foodborne illness [32].

Table 2. Contamination level and identification of the B. cereus group by the polymerase chain reaction (PCR) method and microbial counts of the B. cereus group at each point during the cold chain.

\begin{tabular}{ccccc}
\hline \multirow{2}{*}{ Sampling Point } & \multicolumn{2}{c}{ No. of B. cereus Group Isolates (\%) } & \multirow{2}{\text{Contamination}}{$\begin{array}{c}\text { Level } \\
\text { (Log CFU/g) }\end{array}$} \\
\cline { 2 - 4 } & B. cereus & B. thuringiensis & B. mycoides & $1.9 \pm 0.22$ a,(1),(2) \\
Harvest & $29(100)$ & $0(0)$ & $0(0)$ & $2.9 \pm 0.44^{\mathrm{b}}$ \\
Packaging & $17(100)$ & $0(0)$ & $0(0)$ & $2.6 \pm 0.68^{\mathrm{b}}$ \\
Distribution center & $15(100)$ & $0(0)$ & $0(0)$ & $2.1 \pm 0.26^{\mathrm{ab}}$ \\
Transportation & $10(100)$ & $0(0)$ & $0(0)$ & $2.6 \pm 0.41^{\mathrm{b}}$ \\
Retail shop & $30(100)$ & $0(0)$ & $0(0)$ & $2.4 \pm 0.39$ \\
Total & $101(100)$ & & 0.39
\end{tabular}

(1) Each data point shows the mean \pm standard deviation of triplicated samples. ${ }^{(2)}$ Different superscripts in the same column indicate significant differences $(p<0.05)$.

In fresh-cut vegetable end products, B. cereus levels between 4 and $5 \log$ CFU/g are considered unsatisfactory for consumption, according to the Health Protection Agency guidelines of the United Kingdom for ready-to-eat foods [33]. All samples collected from each point during the cold chain had values less than $3 \log \mathrm{CFU} / \mathrm{g}$, but there is a potential possibility of bacterial contamination in raw fresh vegetables and the risk of foodborne illness outbreak by pathogens is greater when compared to cooked foods as raw vegetables are most often consumed without cooking. Conventional PCR was performed with 101 B. cereus group isolates, and the results supported the identification of B. cereus as all isolates were non-rhizoidal cells and did not harbor the cry gene or the specific gyrB gene for B. thuringiensis.

Low temperatures in the cold chain can effectively control the proliferation of foodborne pathogens [34]. However, the use of long-term cold storage may induce changes in the cellular processes, cell membranes, cell surface protein expression, and ribosome structures that promote efficient survival and proliferation under food environment-associated stress conditions [35]. Psychrotolerant B. cereus isolates, in comparison to non-stress-adapted bacteria, can more easily adapt to other stresses such as $\mathrm{pH}$, heat, and anaerobic conditions $[17,18]$. Thus, monitoring the prevalence of psychrotolerant B. cereus isolates in vegetables throughout the cold chain could be an important food safety factor for predicting the occurrence of outbreaks caused by psychrotolerant B. cereus in fresh vegetables. 


\subsection{Psychrotolerant Properties of B. cereus Isolated from Vegetables}

We collected a total of 101 B. cereus isolates from green leaf lettuce samples. All isolates did not grow at $5{ }^{\circ} \mathrm{C}: 58.4 \%$ among the 101 isolates grew at $12{ }^{\circ} \mathrm{C}, 50.5 \%$ at $10{ }^{\circ} \mathrm{C}, 17.8 \%$ at $7{ }^{\circ} \mathrm{C}$, and none at $5{ }^{\circ} \mathrm{C}$ (Table 3). Among the 18 isolates that grew at $7{ }^{\circ} \mathrm{C}$, the majority (17 isolates, $98 \%$ ) of isolates were collected from green leaf lettuce during transportation from a distribution center to a retail shop. More than $50 \%$ of the isolates could grow at $12{ }^{\circ} \mathrm{C}$ or $10{ }^{\circ} \mathrm{C}$, and approximately $18 \%$ of the isolates were capable of growth at $7{ }^{\circ} \mathrm{C}$; therefore, psychrotolerant $B$. cereus isolates from green leaf lettuce could increase, depending on the storage condition and transport period of the products under low temperatures, considering that refrigeration is the main conservation technology of these products. The psychrotolerant B. cereus isolates may be important in the food industry due to the fact that these isolates are related to the reduction of the shelf life of food products [36], or the increase in the number of microorganisms, which in turn can become a food poisoning problem.

Table 3. Evaluation of the growth of Bacillus cereus isolated from green leaf lettuce incubated at different temperatures.

\begin{tabular}{cccccc}
\hline \multirow{2}{*}{ Sampling Point } & \multirow{2}{*}{$\begin{array}{c}\text { No. of } \\
\text { B. cereus Isolates }\end{array}$} & $\mathbf{1 2}{ }^{\circ} \mathbf{C}$ & $\mathbf{1 0}{ }^{\circ} \mathbf{C}$ & $\mathbf{7}^{\circ} \mathbf{C}$ & $\mathbf{5}^{\circ} \mathbf{C}$ \\
\cline { 3 - 6 } & & $10(34.5)$ & $8(27.6)$ & $0(0)$ & $0(0)$ \\
Harvest & 29 & $12(70.6)$ & $12(70.6)$ & $1(5.9)$ & $0(0)$ \\
Packaging & 17 & $14(93.3)$ & $14(93.3)$ & $6(33.3)$ & $0(0)$ \\
Distribution center & 15 & $7(70)$ & $5(50.0)$ & $4(20.0)$ & $0(0)$ \\
Transportation & 10 & $16(53.3)$ & $12(40.0)$ & $7(23.3)$ & $0(0)$ \\
Retail shop & 30 & $59(58.4)$ & $51(50.5)$ & $18(17.8)$ & $0(0)$ \\
Total & 101 & & & & \\
\hline
\end{tabular}

The psychrotolerant B. cereus group is detected in soil, milk, ice cream, dairy products, rice salad, and spices $[37,38]$. Psychrotrophic B. cereus isolates can become a food poisoning problem when these isolates possess toxin genes to produce diarrheic or emetic syndromes. Recent studies have shown that psychrotolerant $B$. cereus isolates carry virulence toxin genes associated with diarrheal disease (nhe $A C D$ and $h b l A C D$ ), and psychrotolerant $B$. cereus isolates have been shown to produce both HBL and NHE toxins [39-41]. Further studies are necessary to determine the prevalence of psychrotolerant $B$. cereus isolates in various agricultural products supplied throughout the cold chain to evaluate virulence factors, antibiotic resistance, and biofilm formation of these isolates as well as to predict the possible occurrence of foodborne illness.

\subsection{Enterotoxigenic Potential of Psychrotolerant B. cereus Isolates}

HBL, NHE, CytK, EntFM, and cereulide (emetic toxin) are major virulence factors produced by $B$. cereus [42]. To evaluate the food poisoning potential of psychrotolerant $B$. cereus isolates, we investigated the distribution and toxigenic profile of toxin genes, and the results are shown in Table 4. NHE is produced only when all three NHE enterotoxin (nheA, nheB, and nheC) complexes are present [43]. We found that $98 \%$ of the isolates of non-psychrotolerant B. cereus and $94 \%$ of the psychrotolerant B. cereus isolates harbored the NHE complex (the combination of $n h e A$, nheB, and nheC). The production of the HBL enterotoxin composed of B, L2, and L1 subunits depends on the expression of all three genes, namely, $h b l C, h b l D$, and $h b l A$. Thirty percent of the non-psychrotolerant $B$. cereus isolates and $44 \%$ of the psychrotolerant $B$. cereus isolates possessed three coding genes of the HBL complex. The cytK gene, which might cause necrotic enteritis, was detected in $96 \%$ of the mesophilic and $57 \%$ of the psychrotolerant B. cereus isolates. In addition, $88 \%$ of the non-psychrotolerant B. cereus isolates and $78 \%$ of the psychrotolerant $B$. cereus isolates possessed the entFM gene. None of the isolates possessed the ces gene. A total of $23 \%$ of the non-psychrotolerant B. cereus isolates and $28 \%$ of the psychrotolerant $B$. cereus isolates possessed all tested enterotoxin genes. 
Table 4. Frequency and profile of enterotoxigenic non-psychrotolerant and psychrotolerant B. cereus isolated from green leaf lettuce in the cold chain.

\begin{tabular}{|c|c|c|c|}
\hline & \multirow{2}{*}{ Enterotoxin Genes } & \multicolumn{2}{|c|}{ No. $(\%)$ of Entertoxigenic B. cereus } \\
\hline & & $\begin{array}{c}\text { Non-psychrotolerant B. cereus } \\
\qquad(n=83)\end{array}$ & $\begin{array}{c}\text { Psychrotolerant B. cereus } \\
(n=18)\end{array}$ \\
\hline \multicolumn{4}{|c|}{ Frequency of Enterotoxin Genes } \\
\hline 1 & nhe $A B C$ & $81(97.6)$ & $17(94.4)$ \\
\hline 2 & hblACD & $25(30.1)$ & $8(44.4)$ \\
\hline 3 & cytK & $80(96.4)$ & $10(55.6)$ \\
\hline 4 & entFM & $73(88.0)$ & $14(77.8)$ \\
\hline 5 & ces & $0(0.0)$ & $0(0.0)$ \\
\hline \multicolumn{4}{|c|}{ Profile of Enterotoxin Genes } \\
\hline 1 & $\begin{array}{c}\text { nheABC }+ \text { hblACD }+c y t K+ \\
\text { entFM }\end{array}$ & $19(23.2)$ & $5(27.8)$ \\
\hline 2 & nheABC + hblACD + entFM & $0(0.0)$ & $3(16.7)$ \\
\hline 3 & $n h e A B C+c y t K+e n t F M$ & $52(63.4)$ & $3(16.7)$ \\
\hline 4 & nhe $A B C+$ hblACD + entFM & $2(2.4)$ & $0(0.0)$ \\
\hline 5 & nhe $A B C+h b l A C D+c y t K$ & $3(3.7)$ & $0(0.0)$ \\
\hline 6 & nhe $A B C+c y t K$ & $4(4.9)$ & $1(5.6)$ \\
\hline 7 & nhe $A B C+$ entFM & $0(0.0)$ & $1(5.6)$ \\
\hline 8 & $c y t K+e n t F M$ & $2(2.4)$ & $1(5.6)$ \\
\hline 9 & entFM & $0(0.0)$ & $1(5.6)$ \\
\hline 10 & nhe $A B C$ & $1(1.2)$ & $3(16.7)$ \\
\hline
\end{tabular}

We observed that 18 isolates capable of growth at $7^{\circ} \mathrm{C}$ among the $101 \mathrm{~B}$. cereus isolates may have the potential to proliferate in food in response to changes in the optimal environmental conditions of these bacteria or in long-term cold storage. Bartoszewicz et al. [37] reported that psychrotolerant B. cereus harbors well-known toxigenic-associated genes such as $n h e A, h b l A$, and $c y t K$. Most psychrotolerant $B$. cereus isolates have been reported to possess the enterotoxin gene and show high hemolytic activity $[40,44]$. Our data are consistent with those of previous reports showing that psychrotolerant $B$. cereus can grow at refrigeration temperatures and possesses at least two enterotoxin genes. These results suggest that psychrotolerant $B$. cereus isolates from green leaf lettuce may pose a health risk if the enterotoxin genes are expressed during prolonged cold storage.

\subsection{Antibiotic Resistance}

The resistance patterns to 12 antibiotics in 83 non-psychrotolerant B. cereus isolates and 18 psychrotolerant B. cereus isolates were determined, and the results are shown in Table 5 . No difference in the frequency of antibiotic resistance was observed between non-psychrotolerant B. cereus and psychrotolerant B. cereus isolates. All isolates revealed $100 \%$ resistance to penicillin and third-generation cephalosporins and were sensitive to gentamicin, imipenem, ciprofloxacin, erythromycin, and chloramphenicol. This result is consistent with that of a previous report demonstrating that $B$. cereus is susceptible to imipenem, vancomycin, chloramphenicol, ciprofloxacin, erythromycin, and gentamicin [23,45]. In our study, all non-psychrotolerant B. cereus and psychrotolerant B. cereus isolates showed resistance to beta-lactam antibiotics. B. cereus generally produces beta-lactamase and is uniformly resistant to beta-lactam antibiotics including third-generation cephalosporins. B. cereus isolated from ice cream showed sporadic resistance to tetracycline and erythromycin [22]. 
Table 5. Antibiotic resistance patterns of the non-psychrotolerant and psychrotolerant B. cereus isolated from green leaf lettuce in the cold chain.

\begin{tabular}{|c|c|c|c|c|c|c|}
\hline & \multicolumn{6}{|c|}{ No. (\%) of B. cereus Isolates with Indicated Response } \\
\hline & \multicolumn{3}{|c|}{$\begin{array}{l}\text { Non-psychrotolerant } B \text {. cereus } \\
\qquad(n=83)\end{array}$} & \multicolumn{3}{|c|}{$\begin{array}{l}\text { Psychrotolerant B. cereus } \\
(n=18)\end{array}$} \\
\hline & Resistance & Intermediate & Sensitive & Resistance & Intermediate & Sensitive \\
\hline Tetracycline & $13(15.7)$ & $50(60.2)$ & $20(24.1)$ & $2(11.1)$ & $3(16.7)$ & $13(72.2)$ \\
\hline Gentamicin & $0(0.0)$ & $0(0.0)$ & $83(100.0)$ & $0(0.0)$ & $0(0.0)$ & $18(100.0)$ \\
\hline Imipenem & $0(0.0)$ & $0(0.0)$ & $83(100.0)$ & $0(0.0)$ & $0(0.0)$ & $18(100.0)$ \\
\hline Vancomycin & $1(1.2)$ & $0(0.0)$ & $82(98.8)$ & $0(0.0)$ & $0(0.0)$ & $18(100.0)$ \\
\hline Ciprofloxacin & $0(0.0)$ & $0(0.0)$ & $83(100.0)$ & $0(0.0)$ & $0(0.0)$ & $18(100.0)$ \\
\hline Erythromycin & $0(0.0)$ & $0(0.0)$ & $83(100.0)$ & $0(0.0)$ & $0(0.0)$ & $18(100.0)$ \\
\hline Rifampin & 65 (78.3) & 13 (15.7) & $5(6.0)$ & $4(22.2)$ & $6(33.3)$ & $8(44.4)$ \\
\hline Chloraphenicol & $0(0.0)$ & $0(0.0)$ & $83(100.0)$ & $0(0.0)$ & $0(0.0)$ & $18(100.0)$ \\
\hline Clindamycin & $0(0.0)$ & $0(0.0)$ & $83(100.0)$ & $0(0.0)$ & $8(44.4)$ & $10(55.6)$ \\
\hline Penicillin & $83(100.0)$ & $0(0.0)$ & $0(0.0)$ & $18(100.0)$ & $0(0.0)$ & $0(0.0)$ \\
\hline Ceftriaxone & $83(100.0)$ & $0(0.0)$ & $0(0.0)$ & $18(100.0)$ & $0(0.0)$ & $0(0.0)$ \\
\hline Cefotaxim & $83(100.0)$ & $0(0.0)$ & $0(0.0)$ & $18(100.0)$ & $0(0.0)$ & $0(0.0)$ \\
\hline
\end{tabular}

In this study, $16 \%$ of the non-psychrotolerant B. cereus isolates showed resistance to tetracycline, and $60 \%$ of the isolates revealed an intermediate level of resistance to this antibiotic. These findings are consistent with those of other researchers who reported that $7 \%$ of the isolates from cereal, ice cream, and soil were resistant to tetracycline [22]. A high number (60\%) of psychrotolerant B. cereus isolates showed an intermediate level of resistance to tetracycline. Intermediate level resistance (low-level resistance) is often underestimated. It is not only a gateway to high-level clinical resistance, but is also a gateway to often unsuspected phenomena such as increased bacterial adaptation to antibiotics [46]. Antibiotic resistance in foodborne pathogens has become a serious problem in many parts of the world, emphasizing the need to better understand the mechanisms involved in the emergence and spread of resistant strains [46].

Rifampin is a bactericidal antibiotic effective against a wide variety of bacteria, but $B$. cereus is frequently resistant to rifampin [47]. In this study, $78 \%$ of non-psychrotolerant $B$. cereus and $22 \%$ of psychrotolerant $B$. cereus isolates were resistant to rifampin. B. cereus isolates from agricultural products showed a high frequency of resistance to rifampicin [21], and more than $60 \%$ of B. cereus isolates from cereal and rice have been shown to be resistant to rifampicin [48]. In contrast, isolates from dairy products and ready-to-eat products show sensitivity to rifampin [49,50]. Only one psychrotolerant $B$. cereus isolate showed resistance to vancomycin. All non-psychrotolerant $B$. cereus isolates were sensitive to clindamycin, whereas $45 \%$ of the psychrotolerant $B$. cereus isolates displayed intermediate resistance to clindamycin.

Antibiotic therapy is still the primary treatment method for infections of $B$. cereus. However, antibiotic-resistant $B$. cereus can easily spread at each stage of the food chain, and may reach humans indirectly through the consumption of contaminated food or food derived products [51]. Under suitable conditions, some bacteria can either induce the onset of a disease or transfer the gene that provides antibiotic resistance to other bacterial pathogens [52]. Furthermore, when bacteria are exposed to environmental stress, they may undergo phenotypic and genotypic changes to enhance their survival in a stressful environment [53]. These changes may give rise to cross-protection when these bacteria are exposed to secondary stresses, which may also subsequently change their antibiotic resistance profiles [54]. McMahon et al. found that when Escherichia coli, Salmonella enterica serovar Typhimurium, and S. aureus were exposed to sublethal food preservation stresses, their antibiotic sensitivity profiles changed [55]. The difference in the antibiotic susceptibility profile between non-psychrotolerant B. cereus and psychrotolerant $B$. cereus isolates may be due to changes in the phenotype and genotypic properties of -low-temperature-tolerant bacterial isolates. 


\subsection{Biofilm Formation}

A biofilm is a multicellular complex formed by microorganisms that are attached to a surface and are embedded in a matrix consisting of exopolymeric substances (EPS). Cells within a biofilm are surrounded by the EPS matrix and cells in the outer layers of the biofilm, protecting them from harsh influences from the environment. Therefore, cells surrounded by biofilms can be resistant to antimicrobial substances or cleaning agents [56]. The ability of non-psychrotolerant $B$. cereus and psychrotolerant $B$. cereus isolates to produce biofilms on a microtiter plate at $7{ }^{\circ} \mathrm{C}, 10^{\circ} \mathrm{C}$, and $30^{\circ} \mathrm{C}$ is shown in Figure 2. At $30^{\circ} \mathrm{C}$, five $(6.1 \%)$ of the non-psychrotolerant B. cereus isolates had moderate biofilm formation abilities, and $19.5 \%$ of the isolates had weak biofilm formation abilities. At $10{ }^{\circ} \mathrm{C}$, four isolates (approximately $5 \%$ ) were moderate biofilm formers, and 25 isolates (30.5\%) were weak biofilm formers. Ten percent of non-psychrotolerant $B$. cereus isolates had a weak biofilm-formation ability, but most of the isolates $(90 \%)$ did not produce a biofilm at $7^{\circ} \mathrm{C}$. No isolate was a strong biofilm former among the entire non-psychrotolerant $B$. cereus isolates.

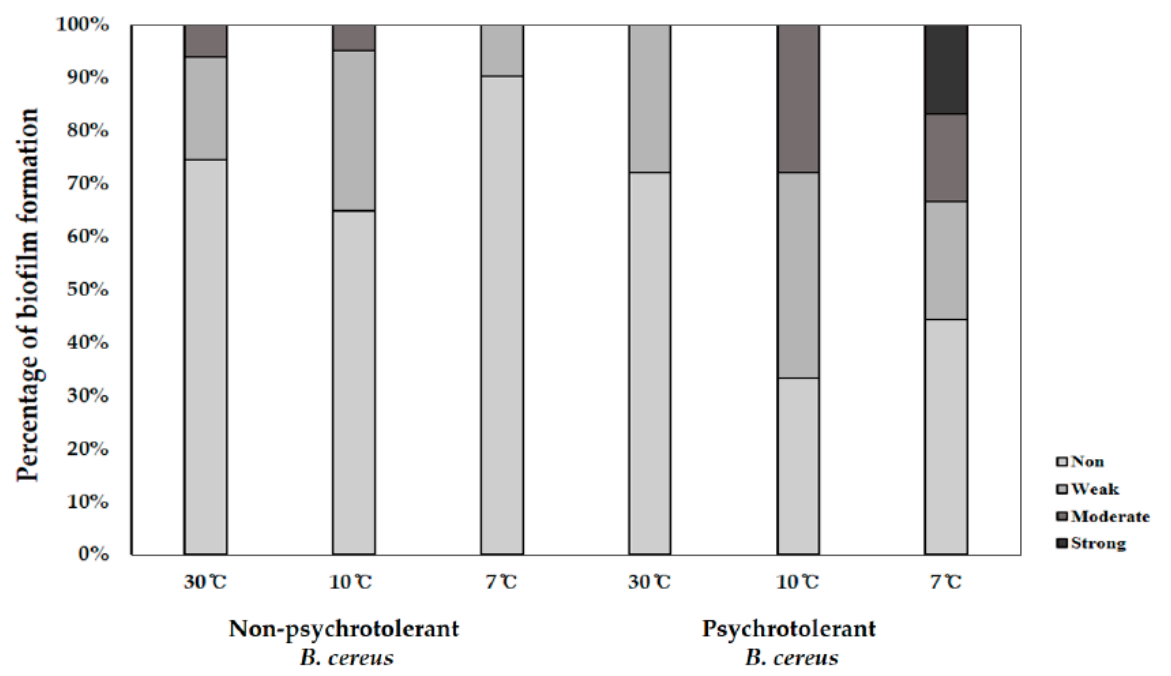

Figure 2. Biofilm phenotype (\%) of non-psychrotolerant and psychrotolerant B. cereus isolated from green leaf lettuce in the cold chain.

In contrast, psychrotolerant $B$. cereus isolates showed a higher biofilm formation ability at $7{ }^{\circ} \mathrm{C}$ than at $10^{\circ} \mathrm{C}$ or $30^{\circ} \mathrm{C}$. Among psychrotolerant $B$. cereus isolates, all were non- or weak biofilm formers at $30^{\circ} \mathrm{C}$, and $38.5 \%$ of the isolates had moderate biofilm-forming ability at $10{ }^{\circ} \mathrm{C}$. Interestingly, of the psychrotolerant $B$. cereus isolates, at $7{ }^{\circ} \mathrm{C}, 23 \%$ were strong and moderate biofilm formers, and $15 \%$ were weak biofilm formers. Only three psychrotolerant B. cereus isolates $(16.6 \%)$ were strong biofilm formers at $7{ }^{\circ} \mathrm{C}$, in contrast to the psychrotolerant $B$. cereus isolates with no strong biofilm former.

Cells in biofilm are more resistant to disinfectant treatment and stress conditions, and the biofilm formation of some psychrotolerant $B$. cereus isolates under low temperature can be difficult to disinfect foodstuff or food contact surfaces and the possibility of cross-contamination during food processing $[57,58]$. In this study, psychrotolerant B. cereus isolates had greater biofilm-formation abilities than non- psychrotolerant $B$. cereus isolates at low temperatures. This result is in agreement with that of Sarita et al. [57], who showed that B. cereus isolates from a chiller tank containing pasteurized milk were able to form a biofilm even at $4{ }^{\circ} \mathrm{C}$. In contrast, $B$. cereus isolated from food products could grow at low temperatures, but the isolates were unable to form a biofilm at $7^{\circ} \mathrm{C}$ [28]. The growth of most B. cereus isolates is generally inhibited when temperature is below $10^{\circ} \mathrm{C}$ and forms strong biofilms on a microtiter plate at $30^{\circ} \mathrm{C}$. In this study, however, some psychrotolerant B. cereus isolates could grow at refrigerated temperature and these isolates in biofilm were more resistant to low temperatures than optimal temperature, especially for the transport, retail, and processing of agricultural products such as vegetables, which are typically stored between $0-10{ }^{\circ} \mathrm{C}$, where psychrotolerant $B$. cereus adapted to 
cold stress and protected themselves against the cold shift. The results suggest that low temperature may fail to restrain the growth and biofilm formation of some B. cereus isolates in vegetables, therefore presents a potential risk in food safety.

Biofilm formation is enhanced by cell motility, particularly when biofilm is mediated by flagella, and under certain environmental conditions, flagella are necessary for B. cereus biofilm formation [59]. The integration of many diverse signals from the environment, together with other events such as phenotypic and genetic switching during biofilm production and the release of extracellular polymeric substances, might play a role in biofilm formation [60]. Thus, the biofilm-formation ability of psychrotolerant isolates could be due to modified bacterial characteristics (flagella, EPS, growth phase, metabolic activity, etc.) that are temperature dependent. However, further study is necessary to understand the mechanism of biofilm formation by psychrotolerant B. cereus isolates.

\section{Conclusions}

B. cereus is the predominant species isolated from agricultural products including green leaf lettuce. Low-temperature-tolerant $B$. cereus isolates are associated with potential health risks as these isolates share the enterotoxin gene with mesophilic isolates. Psychrotolerant $B$. cereus isolates can also form strong biofilms, which hampers food industry surface decontamination and increases the possibility of cross-contamination during food processing. The prevalence and pathogenicity of psychrotolerant B. cereus during the cold chain cannot be ignored from the aspect of food safety.

Author Contributions: Conceptualization, M.K.; Investigation, K.M.P.; Resources, M.J.; Validation, H.J.K. and M.J.; Writing_original draft, K.M.P and M.K.; Writing—review and editing, K.M.P. and M.K.; Supervision, M.K. All authors have read and agreed to the published version of the manuscript.

Funding: This study was conducted with the support of the Korea Food Research Institute (E0192101-01) and the High Value-added Food Technology Development Program of the Korea Institute of Planning and Evaluation for Technology in Food, Agriculture, Forestry and Fisheries, Republic of Korea (No. 316068-3).

Conflicts of Interest: The authors declare no conflicts of interest associated with this manuscript.

\section{References}

1. Hertog, M.L.A.T.M.; Uysal, I.; McCarthy, U.; Verlinden, B.M.; Nicolai, B.M. Shelf life modelling for first-expired-first-out warehouse management. Philos. Trans. A Math. Phys. Eng. Sci. 2014, 372, 20130306. [CrossRef]

2. Sorhaug, T.; Stepaniak, L. Psychrotrophs and their enzymes in milk and dairy products: Quality aspects. Trends Food Sci. Technol. 1997, 8, 35-41. [CrossRef]

3. Wouters, J.A.; Rombouts, F.M.; Kuipers, O.P.; de Vos, W.M.; Abee, T. The role of cold-shock proteins in low-temperature adaptation of food-related bacteria. Syst. Appl. Microbiol. 2000, 23, 165-173. [CrossRef]

4. Forghani, F.; Kim, J.B.; Oh, D.H. Enterotoxigenic profiling of emetic toxin and enterotoxin-producing Bacillus cereus, isolated from food, environmental, and clinical samples by Multiplex PCR. J. Food Sci. 2014, 79, 2288-2293. [CrossRef] [PubMed]

5. Jo, M.J.; Jeong, A.R.; Kim, H.J.; Lee, N.R.; Oh, S.W.; Kim, Y.J.; Chun, H.S.; Koo, M.S. Microbiological quality of fresh-cut produce and organic vegetables. Korean J. Food Sci. Technol. 2011, 43, 91-97. [CrossRef]

6. Agata, N.; Ohta, M.; Mori, M.; Isobe, M. A novel dodecadepsipeptide, cereulide, is an emetic toxin of Bacillus cereus. FEMS Microbiol. Lett. 1995, 129, 17-20.

7. Kramer, J.M.; Gilbert, R.J. Bacillus cereus and other Bacillus species. In Foodborne Bacterial Pathogens; Marcel Dekker Inc.: New York, NY, USA, 1989.

8. Granum, P.E. Bacillus cereus and its toxins. Soc. Appl. Bacteriol. Symp. Ser. 1994, 23, 61-66.

9. Anderson, A.; Ronener, U.; Granum, P.E. What problems does the food industry have with the spore-forming pathogens Bacillus cereus and Clostridium perfringens? Int. J. Food Microbiol. 1995, 28, 145-155. [CrossRef]

10. Lindsay, D.; Brözel, V.S.; Von Holy, A. Biofilm-spore response in Bacillus cereus and Bacillus subtilis during nutrient limitation. J. Food Prot. 2006, 69, 1168-1172. [CrossRef]

11. Samie, N.; Noghabi, K.; Gharegozloo, Z.; Zahiri, H.; Ahmadian, G.; Sharafi, H. Psychrophilic $\alpha$-amylase from Aeromonas veronii NS07 isolated from farm soils. Process. Biochem. 2012, 47, 1381-1387. [CrossRef] 
12. Larsen, H.D.; Jørgensen, K. The occurrence of Bacillus cereus in Danish pasteurized milk. Int. J. Food Microbiol. 1997, 34, 179-186. [CrossRef]

13. Meer, R.R.; Baker, J.; Bodyfelt, F.W.; Griffiths, M.W. Psychrotrophic Bacillus spp. in fluid milk products: A review. J. Food Prot. 1991, 54, 969-979. [CrossRef] [PubMed]

14. Huck, J.R.; Hammond, B.H.; Murphy, S.C.; Woodcock, N.H.; Boor, K.J. Tracking spore-forming bacterial contaminants in fluid milk-processing systems. J. Dairy Sci. 2007, 90, 4872-4883. [CrossRef] [PubMed]

15. Baron, F.; Cochet, M.F.; Grosset, N.; Madec, M.N.; Briandet, R.; Dessaigne, S.; Chevalier, S.; Gautier, M.; Jan, S. Isolation and characterization of a psychrotolerant toxin producer, Bacillus weihenstephanensis in liquid egg products. J. Food Prot. 2007, 70, 2782-2791. [CrossRef] [PubMed]

16. Stenfors Arnesen, L.; Granum, P.E.; Buisson, C.; Bohlin, J.; Nielsen-LeRoux, C. Using an insect model to assess correlation between temperature and virulence in Bacillus weihenstephanensis and Bacillus cereus. FEMS Microbiol. Lett. 2011, 317, 196-202. [CrossRef]

17. Guerin, A.; Dargaignaratz, C.; Broussolle, V.; Clavel, T.; Nguyen-the, C. Combined effect of anaerobiosis, low $\mathrm{pH}$ and cold temperatures on the growth capacities of psychrotrophic Bacillus cereus. Food Microbiol. 2016, 59, 119-123. [CrossRef]

18. Choma, C.; Guinebretiere, M.H.; Carlin, F.; Schmitt, P.; Velge, P.; Granum, P.E.; Nguyen-The, C. Prevalence, characterization and growth of Bacillus cereus in commercial cooked chilled foods containing vegetables. J. Appl. Microbiol. 2000, 88, 617-625. [CrossRef]

19. Dancer, S.J. Mopping up hospital infection. J. Hosp. Infect. 1999, 43, 85-100. [CrossRef]

20. Berthold-Pluta, A.; Garbowska, M.; Stefanska, I.; Pluta, A. Microbiological quality of selected ready-to-eat leaf vegetables, sprouts and non-pasteurized fresh fruit-vegetable juices including the presence of Cronobacter spp. Food Microbiol. 2017, 65, 221-230. [CrossRef]

21. Park, K.M.; Jeong, M.; Park, K.J.; Koo, M. Prevalence, enterotoxin genes, and antibiotic resistance of Bacillus cereus isolated from raw vegetables in Korea. J. Food Prot. 2018, 81, 1590-1597. [CrossRef]

22. Ozcelik, B.; Citak, S. Evaluation of antibiotic resistance of Bacillus cereus isolates in ice cream samples sold in Ancara. Turk. J. Pharm. Sci. 2009, 6, 231-238.

23. Al-Khatib, M.S.; Khyami-Horani, H.; Badran, E.; Shehabi, A. Incidence and characterization of diarrheal enterotoxins of fecal Bacillus cereus isolates associated with diarrhea. Diagn. Microbiol. Infect. Dis. 2007, 59, 383-387. [CrossRef] [PubMed]

24. van Netten, P.; van De Moosdijk, A.; van Hoensel, P.; Mossel, D.A.; Perales, I. Psychrotrophic strains of Bacillus cereus producing enterotoxin. J. Appl. Bacteriol. 1990, 69, 73-79. [CrossRef] [PubMed]

25. Korea Food and Drug Administration (KFDA). Food Code. Available online: http://www.kfda.go.kr (accessed on 1 October 2019).

26. Yamada, S.; Ohashi, E.; Agata, N.; Venkateswaran, K. Cloning and nucleotide sequence analysis of $g y r B$ of Bacillus cereus, B. thuringiensis, B. mycoides, and B. anthracis and their application to the detection of $B$. cereus in rice. Appl. Environ. Microbiol. 1999, 65, 1483-1490. [CrossRef] [PubMed]

27. Święcicka, I.; Mahillon, J. Diversity of Commensal Bacillus cereus sensu lato isolated from the common sow bug (Porcellio scaber, Isopoda). FEMS Microbiol. Ecol. 2006, 56, 132-140. [CrossRef]

28. Clinical and Laboratory Standards Institute (CLSI). Performance Standards for Antimicrobial Susceptibility Testing; Clinical and Laboratory Standards Institute: Tempe, AZ, USA, 2014.

29. Singh, A.K.; Prakash, P.; Achra, A.; Singh, G.P.; Das, A.; Singh, R.K. Standardization and classification of in vitro biofilm formation by clinical isolates of Staphylococcus aureus. J. Glob. Infect. Dis. 2017, 9, 93-101.

30. Chon, J.W.; Yim, J.H.; Kim, H.S.; Kim, D.H.; Kim, H.; Oh, D.H. Quantitative prevalence and toxin gene profile of Bacillus cereus from ready-to-eat vegetables in South Korea. Foodborne Pathog. Dis. 2015, 12, 795-799. [CrossRef]

31. Kim, H.J.; Koo, M.; Hwang, D.; Choi, J.H.; Kim, S.M.; Oh, S.W. Contamination patterns and molecular typing of Bacillus cereus in fresh-cut vegetable salad processing. Appl. Biol. Chem. 2016, 59, 573-577. [CrossRef]

32. Valero, M.; Hernandez-Herrero, L.A.; Fernandez, P.S.; Salmeron, M.C. Characterization of Bacillus cereus isolates from fresh vegetables and refrigerated minimally processed foods by biochemical and physiological tests. Food Microbiol. 2002, 19, 491-499. [CrossRef]

33. European Food Safety Authority (EFSA). Risks for public health related to the presence of Bacillus cereus and other Bacillus spp. including Bacillus thuringiensis in foodstuffs. EFSA J. 2016, 14, 4524-4593. 
34. Walker, S.J.; Archer, P.; Banks, J.G. Growth of Listeria monocytogenes at refrigeration temperatures. J. Appl. Bacteriol. 1990, 68, 157-162. [CrossRef] [PubMed]

35. Tasara, T.; Stephan, R. Cold stress tolerance of Listeria monocytogenes: A review of molecular adaptive mechanisms and food safety implications. J. Food Prot. 2006, 69, 1473-1484. [CrossRef] [PubMed]

36. Samapundo, S.; Heyndrickx, M.; Xhaferi, R.; Devlieghere, F. Incidence, diversity and toxin gene characteristics of Bacillus cereus group strains isolated from food products marketed in Belgium. Int. J. Food Microbiol. 2011, 150, 34-41. [CrossRef] [PubMed]

37. Bartoszewicz, M.; Bideshi, D.K.; Kraszewska, A.; Modzelewska, E.; Swiecicka, I. Natural isolates of Bacillus thuringiensis display genetic and psychrotrophic properties characteristic of Bacillus weihenstephanensis. J. Appl. Microbiol. 2009, 106, 1967-1975. [CrossRef]

38. Guoping, Z.; Dasheng, Z.; Lina, D.; Quanxin, C.; Zhiming, Y. Occurrence of psychrotrophic Bacillus cereus group strains in ice creams. Int. J. Food Microbiol. 2010, 137, 143-146.

39. Kovac, J.; Miller, R.A.; Carroll, L.M.; Kent, D.J.; Jian, J.; Beno, S.M. Production of hemolysin BL by Bacillus cereus group isolates of dairy origin is associated with whole-genome phylogenetic clade. BMC Genom. 2016, 17, 581-596. [CrossRef]

40. Miller, R.A.; Beno, S.M.; Kent, D.J.; Carroll, L.M.; Martin, N.H.; Boor, K.J. Bacillus wiedmannii sp. nov. is a new psychrotrophic and cytotoxic Bacillus cereus group species isolated from dairy foods and environments in the USA. Int. J. Syst. Evol. Microbiol. 2016, 66, 4744-4753. [CrossRef]

41. Miller, R.A.; Jian, J.; Beno, S.M.; Wiedmann, M.; Kovac, J. Genomic and phenotypic characterization of type strains and dairy-associated isolates in the Bacillus cereus group indicates considerable intra-clade variability in toxin production and cytotoxicity. Appl. Environ. Microbiol. 2018, 84, 2479-2517. [CrossRef]

42. Ngamwongsatit, P.; Buasri, W.; Pianariyanon, P.; Pulsrikan, C.; Ohba, M. Broad distribution of enterotoxin genes ( $h b l C D A$, nhe $A B C$, cytK, and entFM) among Bacillus thuringiensis and Bacillus cereus as shown by novel primers. Int. J. Food Microbiol. 2008, 121, 352-356. [CrossRef]

43. Ryan, P.A.; MacMillan, J.D.; Zilinskas, B.A. Molecular cloning and characterization of the genes encoding L1 and L2 components of hemolysin BL from Bacillus cereus. J. Bacteriol. 1997, 179, 2551-2556. [CrossRef]

44. Merzougui, S.; Cohen, N.; Grosset, N.; Gautier, M.; Lkhider, M. Enterotoxigenic Profiles of psychrotrophic and mesophilic strains of the Bacillus cereus group isolated from food in Morocco. Int. J. Eng. Res. Appl. 2013, 3, 964-970.

45. Oladipo, I.C.; Adejumobi, O.D. Incidence of antibiotic resistance in some bacterial pathogens from street vended food in Ogbomoso, Nigeria. Pak. J. Nutr. 2010, 9, 1061-1068. [CrossRef]

46. Goldstein, F. The potential clinical impact of low level antibiotic resistance in Staphylococcus aureus. J. Antimicrob. Chemother. 2007, 59, 1-4. [CrossRef] [PubMed]

47. Campbell, E.; Korzheva, N.; Mustaev, A.; Murakami, K.; Nair, S.; Goldfarb, A.; Darst, S.A. Structural mechanism for rifampicin inhibition of bacterial RNA polymerase. Cell 2001, 104, 901-912. [CrossRef]

48. Park, Y.B.; Kim, J.B.; Shin, S.W.; Kim, J.C.; Cho, S.H.; Lee, B.K.; Ahn, J.; Kim, J.M.; Oh, D.H. Prevalence, genetic diversity, and antibiotic susceptibility of Bacillus cereus strains isolated from rice and cereals collected in Korea. J. Food Prot. 2009, 72, 612-617. [CrossRef] [PubMed]

49. Agwa, O.K.; Uzoigwe, C.I.; Wokoma, E.C. Incidence and antibiotic sensitivity of Bacillus cereus isolated from ready to eat foods sold in some markets in portharcourt, rivers state, Nigeria. Asian J. Microbiol. Biotechnol. Environ. Sci. 2012, 14, 13-18.

50. Owusu-Kwarteng, J.; Wuni, A.; Akabanda, F.; Tano-Debrah, K.; Jespersen, L. Prevalence, virulence factor genes and antibiotic resistance of Bacillus cereus sensu lato isolated from dairy farms and traditional dairy products. BMC Microbiol. 2017, 17, 65-72. [CrossRef]

51. Chang, Q.; Wang, W.; Regev-Yochay, G.; Lipsitch, M.; Hanage, W.P. Antibiotics in agriculture and the risk to human health: How worried should we be? Evol. Appl. 2015, 8, 240-245. [CrossRef]

52. Byington, C.L.; Enriquez, F.R.; Hoff, C.; Tuohy, R.; Taggart, E.W.; Hillyard, D.R.; Carroll, K.C.; Christenson, J.C. Serious bacterial infections in febrile infants 1 to 90 days old with and without viral infections. Pediatrics 2004, 113, 1662-1666. [CrossRef]

53. Storz, G.; Hengge-Aronis, R. Bacterial Stress Responses; ASM Press: Washington, DC, USA, 2000.

54. Poole, K. Bacterial stress responses as determinants of antimicrobial resistance. J. Antimicrob. Chemother. 2012, 67, 2069-2089. [CrossRef] 
55. Mc Mahon, M.A.S.; Blair, I.S.; Moore, J.E.; Mc Dowell, D.A. The rate of horizontal transmission of antibiotic resistance plasmids is increased in food preservation-stressed bacteria. J. Appl. Microbiol. 2007, 103, 1883-1888. [CrossRef]

56. Peng, J.S.; Tsai, W.C.; Chou, C.C. Inactivation and removal of Bacillus cereus by sanitizer and detergent. Int. J. Food Microbiol. 2002, 77, 11-18. [CrossRef]

57. Sarita, K.; Sarkar, P.K. In vitro model study for biofilm formation by Bacillus cereus in dairy chilling tanks and optimization of clean-in-place (CIP) regimes using response surface methodology. Food Control. 2014, 36, 153-158.

58. Fernandes, M.D.S.; Fujimoto, G.; Schneid, I.; Kabuki, D.Y.; Kuaye, A.Y. Enterotoxigenic profile, antimicrobial susceptibility, and biofilm formation of Bacillus cereus isolated from ricotta processing. Int. Dairy J. 2014, 38, 16-23. [CrossRef]

59. Karatan, E.; Watnick, P. Signals, regulatory networks, and materials that build and break bacterial biofilms. Microbiol. Mol. Biol. Rev. 2009, 73, 310-347. [CrossRef] [PubMed]

60. Simoes, L.C.; Simoes, M.; Vieira, M.J. Adhesion and biofilm formation on polystyrene by drinking water-isolated bacteria. Antonie Leeuwenhoek Int. J. Gen. 2010, 98, 317-329. [CrossRef]

(C) 2020 by the authors. Licensee MDPI, Basel, Switzerland. This article is an open access article distributed under the terms and conditions of the Creative Commons Attribution (CC BY) license (http://creativecommons.org/licenses/by/4.0/). 